Krzysztof Ficoń

Akademia Marynarki Wojennej, Wydział Dowodzenia i Operacji Morskich

Grzegorz Krasnodębski

Akademia Marynarki Wojennej, Wydział Dowodzenia i Operacji Morskich

\title{
Suboptymalizacja krytycznych parametrów kolejki w systemach masowej obsługi
}

\author{
Suboptimalization of critical railway parametrs in massage \\ systems
}

W pracy wskazano na możliwość wykorzystania teorii masowej do optymalizacji krytycznych parametrów kolejek, będących zmorą współczesnej cywilizacji, nie tylko społecznej. Przeanalizowano mechanizm powstawania kolejek, za pomocą metod rachunku prawdopodobieństwa zidentyfikowano jego przyczyny i skutki. Rozważania teoretyczne zilustrowano na drodze analitycznej analizując dwa przykładowe warianty badawcze. Przedmiotem badań były krytyczne parametry kolejki, obejmujące średnią długość kolejki i średni czas oczekiwania. W wariancie pierwszym skupiono się na sterowaniu intensywnością strumienia zgłoszeń, natomiast w wariancie drugim przyjęto bardziej praktyczne sterowanie intensywnością strumienia obsługi.

Stowa kluczowe:

kolejka, czas oczekiwania, zgłoszenia, obsługa

The paper indicates the possibility of using mass theory to optimize the critical parameters of queues, which are the bane of modern civilization, not only social. The mechanism of queuing was analyzed, its causes and effects were identified using probability calculus methods. Theoretical considerations are illustrated by analytical analysis of two example research variants. The subject of the research were the critical parameters of the queue, including the average queue length and average waiting time. The first variant focused on controlling the intensity of the notification stream, while the second variant adopted a more practical control of the intensity of the service stream.

Key words:

queue, waiting time, applications, service

str. 31-39

\section{Bibliografia}

Czujew J. (1973), Badania operacji w wojsku. Wyd. MON Warszawa, s. 225

Erlang A. K. (1917), Solution of some Problems in the Theory of Probabilities of Significance in Automatic Telephone Exchanges. „Elektrotkeknikeren”, vol 13/1917.

Ficoń K. (2017), Zastosowanie teorii masowej obsługi do analizy systemu zabezpieczenia logistycznego sytuacji kryzysowych. ZN WAT SLW nr 47/2017.

Ficoń K. (2018), Port morski jako wielokanałowy system masowej obsługi. Gospodarka magazynowa \& Logistyka, nr $12 / 2018$.

Gniedenko B., Kowalenko N. (1971), Wstęp do teorii masowej obsługi. PWN Warszawa.

Houlden B. T. (red.) (1964), Z praktyki badań operacyjnych. PWE Warszawa. 
Kendall D. G. (1951), Some problems in the theory of gueues. Journal of the Royal Statistical Society ser. B no 13/1951. Koning D., Stoyan D. (1979), Metody teorii masowej obsługi. WN-T Warszawa.

Kopocińska I., O pewnym modelu z teorii kolejek z uwzględnieniem zniecierpliwienia klientów. IM PAN „Zastosowania Matematyki" nr 7/1963.

Kopociński B. (1977), Zarys teorii odnowy i niezawodności. PWN Warszawa 1973.

Koźniewska I., Włodarczyk M. (1978), Modele odnowy, niezawodności i masowej obsługi. PWN Warszawa. Łukaszewicz J. (1965), Teoria kolejek, czyli obsługi masowej. IM PAN „Zastosowania Matematyki” 8/1965.

Nogalski B., Czerska J., Klimek A. (2010), Wykorzystanie metod teorii masowej obsługi i lean management w usprawnianiu procesów w zarządzaniu organizacją publiczną. Współczesne Zarządzanie nr 1/2010.

Obretenow A. Dimitrow B. (1989), Teoria masowej obsługi. Poradnik. PWN Warszawa.

Rozenberg W., Prochorow A. (1972), Teoria masowej obsługi. PWE Warszawa.

Wołodin B. G. i inni (1966), Problemy rachunku prawdopodobieństwa. PWN Warszawa.

Zitek F. (1973), Stracony czas. Elementy teorii obsługi masowej. PWN Warszawa. 